\title{
THE SEARCH FOR SUSTAINABLE EDUCATION IN POST-COLONIAL AFRICAN STATES
}

\author{
Aare Afe Babalola*
}

DOI: https://dx.doi.org/10.4314/jsdlp.v9i1.8

\section{INTRODUCTION}

The Director of the African Studies Centre and Rhodes Professor of Race Relations, Professor Wale Adebanwi; members of the Senior Leadership Team of Oxford University here present; distinguished faculty, staff and students; ladies and gentlemen.

I consider it a great honour to be invited to deliver this lecture at the world's leading centre for the study of Africa - the Oxford African Studies Centre. All noble and self-respecting Africans, including my humble self, have reasons to be exceedingly proud of the great work that this Centre has championed since its establishment, most especially its vision to consolidate the rich and important relationship between the continent of Africa and the prestigious Oxford University.

Oxford University has, over the past century, nurtured some of Africa's most prominent leaders. As you know, the long list includes John Kufour, former President of Ghana, Pixley Ka Isaka Seme (1881 June 1951), the intelligent South African who founded the African National Congress in the early 20th century; Bram Fischer, the antiapartheid activist and lawyer who defended Nelson Mandela at his treason trial; and of course Nigeria's most famous Oxford University graduate, Dim Emeka Odumegwu Ojukwu. It may also interest you to know that on my entourage today is Professor Damilola Olawuyi, an Oxford Doctorate in Law graduate, and a Professor of Law at Afe Babalola University.

* OFR, CON, SAN, LL.D, FNAILS, FCI.Arb. President Emeritus and Founder, Afe Babalola University, Ado Ekiti. This keynote lecture was delivered on 1 May 2018 at the African Studies Centre, School of Interdisciplinary Area Studies, University of Oxford, United Kingdom. 
It was the late Cecil Rhodes who once remarked that "wherever you turn your eye, an Oxford man is at the top of the tree". I beg to assert that in today's world, "wherever you turn your eye, an African Oxford person is at the top of the cadre". The history of Oxford University is incomplete without Africans, and the history of Africa is incomplete without the fundamental contributions and influence of Oxonians. I congratulate you all on being part of this noble community of leaders.

\subsection{Writer's Dilemma}

However, capturing the story of Africa often results in a writer's dilemma: despite the high accomplishments of its people in diverse fields of human endeavour, Africa remains the continent that is home to the world's poorest people on earth. The dual identity of Africa, both as the source of civilization and knowledge; and also as the haven of poverty, corruption and diseases, is evident in virtually every facet of life. In my many years as a farmer, an elementary school teacher, secondary school teacher, university lecturer, legal practitioner, former Pro-Chancellor of University of Lagos, former chairman of Committee of Pro-Chancellors of Nigerian Universities and now Founder and Chancellor of Afe Babalola University, "the most successful not-forprofit private university in Nigeria" courtesy of NUC, no sector has given me more concern than Africa's education sector.

\subsection{Education in Crisis}

Education, in most countries in sub-Saharan Africa, is in crisis today. For many years, African Universities have, at a geometric rate, waned in quality, substance and prestige. Over the last two decades, many of our Universities have become classic examples of what American scholar, Gareth Hardin, described as the Tragedy of the Commons. Hardin theorized that assets that are commonly held by members of the public often perish as a result of neglect and lack of proper care. Soon after the independence granted to African countries by the colonial masters, African Universities started experiencing severe dosage of financial starvation, infrastructural decay and political neglect. Those who attended or taught at any Nigerian university between 1965 and 1990 could easily appreciate the extent of the geometric depreciation of necessary physical structures and facilities in our Universities. A combination of lack of adequate funding, dearth of qualitative practical 
training curriculum; and inability to attract the best teaching minds have all stagnated Nigerian institutions of higher learning to the current appalling point whereby the Centre for World University Rankings, and other global rankings that rank Universities based on facilities, programmes and instructional content, mention no African University in the top 500 category. This is in a continent with over 1000 universities.

\subsection{Schools of Thought}

Some scholars cast the blame for the current decline in the quality of education in Africa on pedagogical approaches of colonial education that eroded and devalued traditional African cultures; perpetuated intellectual servitude and technological dependence; and enshrined societal inequality that remain deep-rooted till date.

Some blame the falling standard on the arbitrary partition of Africa by European powers in Berlin in 1884 by lumping together historically incompatible people, independent or antagonistic groups, animists, Christians and Muslims into political units which continue to wobble with widespread intertribal wars, religious and boundary disputes, civil disobedience, pervasive lack of internal democracy within political parties, insurgencies, kidnapping, ferocious terrorist acts, killings, murder and widespread destruction of properties.

As you all know, most if not all these countries have failed to transform into viable nation states thereby rendering attainment of quality education unattainable.

Some blame the "decline" or falling educational standards in Africa post-colonialization, on the failure of African leaders to replicate and consolidate on the modest achievement of the colonial era with respect to qualitative education. Those in this school of thought point to the failure of successive African governments to properly maintain educational institutions and structures that were put in place by colonial authorities and failure of governments to devote significant portions of yearly budget to education.

To demonstrate the incompatibility of the ethnic groups lumped together arbitrarily by the European powers, I have compiled the number of tribes and ethnic groups in each of the areas of influence allocated to each of the European powers at the Berlin Conference in 1884. In Dahomey, now known as Benin Republic, there are 42 ethnic groups, including Yoruba; in Nigeria, there are 370 ethnic groups including Yoruba. In Cameroun, there are 250 ethnic groups. 
In my lecture today, I will demonstrate to you why I align with the last two schools of thought. The search for sustainable education in Africa cannot continue to follow the simplistic argument of blaming the European powers. We must genuinely ask ourselves, what have successive African leaders done to transform into viable states those areas carved out arbitrarily by the European powers in Berlin? What have they done to build upon and improve the colonial structure on education? What can we do to transform the incompatible ethnic groups in each of the areas of influence carved out for the European powers into a nation?

In my lecture today, I will discuss leadership failure by Africa's ruling class, most especially the perennial failures by successive governments to transform the amalgamated tribes into a nation.

Drawing examples from Nigeria, I will unpack the challenges to sustainable education in postcolonial African states. I will then offer practical recommendations on how the current decline in the quality and quantity of education in African countries can be addressed.

I will specifically share with you some practical lessons on how my university, Afe Babalola University, Ado Ekiti, a non-profit university that is barely eight years old, has been able to tackle some of these challenges to maintain its geometric rise and recognition as Africa's fastest growing global university so much so that ABUAD has been acknowledged by UNESCO as a world-class university, while the National Universities Commission (NUC) lauded it as "a miracle, a benchmark, a reference point for other private universities and one of the best things to have happened to education in this part of the world", and also as "a pride of educational system in Nigeria".

\section{EDUCATION IN COLONIAL AFRICA}

I have conducted a survey of the quantity and quality of education during colonial times in Africa to determine where we were; ascertain where we are now; identify how we got here; and then prescribe how we can get to where we need to be.

\subsection{Where We Were}

I pay special tribute to the missionaries mostly from the United Kingdom and Ireland for their courage and determination which eventually led to the abolition of slave trade. Following the abolition of slave trade, 
the colonial powers, bent on colonizing Africa, met in Berlin where they partitioned Africa not for the purpose of enthroning quality education but for selfish economic reasons. It was the missionaries that introduced Western education into African countries south of the Sahara. However, using West Africa as an example, the British education department subsidized the missionaries' effort. The missionaries went ahead and set up a number of primary, secondary and tertiary schools, despite the economic depression of the late 1930s.

These schools include St. Thomas Primary School, Badagry, Lagos, followed by Hope Waddell Primary School, Calabar, which was established in 1895, by Reverend Hope M. Waddell of the Church of Scotland Mission.

This was followed with the establishment of the CMS Grammar School, Lagos, by the Christian Mission Society (CMS) on 6 June 1859 and Methodist Boys High School (MBHS), Lagos, founded by the Methodist Church on 14 March 1878.

Compared to French colonies, the British colonies had a significantly higher number of secondary schools and universities, ranging from the Fourah Bay College in Sierra Leone (established in 1877), Achimota College in the Gold Coast, Yaba Higher College in Lagos (established in 1934), the Liberia College in Monrovia (1833), the William Ponty School in French West Africa, Makerere College (now University) in Uganda (1933), the Kenya Teacher Training College (1939), the University of Cape Town in South Africa and the University College Ibadan, which was established in 1948 as Nigeria's first University. ${ }^{1}$

The high investment approach to education led to a geometric rise in an educated class of African professionals, teachers and technicians who had the capacity to contribute to the economy and work as support staff to the colonial administration.

In terms of quality, composition and structure, the educational institutions established during the colonial era had the three essential trappings of being autonomous, collegial and self-governing. All of these institutions were meticulously patterned after elite UK Universities such as the University College London and Oxford University. The University of Ibadan (formerly known as University College, Ibadan)

1 See Denis Cogneau, "Colonisation, School and Development in Africa An empirical analysis" (Développement, Institutions et Mondialisation, 2003) < http:/ /www.dial.prd.fr/dial_publications/PDF/Doc_travail/2003-01.PDF > accessed 12 March 2018. 
was run as a classical UK University, controlled solely through a democratic system operated and run by tenured professors and scholars.

This model of university governance began to fade after independence due to several reasons. One chief reason is the Amalgamation of incompatible peoples as nations and the frail and structurally defective federal structure put in place by the colonial leadership, which began to collapse post-colonialization. Take Nigeria, for instance, there is a general consensus that the amalgamation of Northern and Southern Nigeria to form one country in January 1914, was a mistake (often described in the literature as the Mistake of 1914). The Central, Eastern, Northern and Western Regions of Nigeria had divergent cultures and belief systems; different religions; distinct languages; and most importantly dissimilar interest in formal education. While the Western Region believed very strongly in formal education and launched an ambitious investment in free education under the leadership of Chief Obafemi Awolowo; the North believed more in pastoralism, agriculture and informal and largely Islamic education; while the East was the home of industrialists and tradesmen. Thus, at the end of the Amalgamation in 1914, even the colonial authorities struggled to understand a functional and coherent structural direction to which the new Nigerian state should evolve. Studies show that the official records of Mr A. J. Harding, a clerk in the Colonial Office, after reading through Lugard's proposal for the Amalgamation of 1914, concluded that the emergent state would be "impossible to classify". He warned that:

...it is not a unitary state with Local Government Areas but a Central Executive and Legislature. It is not a Federal State with Federal Executive, Legislative and finances, in addition to Provincial Executive, Legislatures and finances. It is not a personal union of separate colonies under the same Governor. It is not a confederation of states. If adopted, his proposal can hardly be a permanent solution.

With one man in practical control of the Executive and Legislative organs of all the parts, the machine may work possibly for sufficient time to enable the transition period to be left behind, by which time the answer to the problem - unitary state or federal - would probably have become clear. ${ }^{2}$

Mr Harding further described Lord Lugard's Amalgamation idea as

2 Public Records Office, Colonial Office, London, Vol. 583. Amalgamation Reports. 
an "unauthorised scheme", and recommended breaking the country into four provinces, namely, the Central, Eastern, Northern and Western Provinces. ${ }^{3}$ Perhaps this was why our first National Anthem cautiously acknowledged that "though tribes and tongue may differ, in brotherhood we stand."

Unfortunately, the patched amalgamation proceeded, and the story of the Nigerian nation has remained that of consistent struggle to find purpose and direction in a fantastically diverse political configuration. This is a struggle that has unfortunately continued till date. Several constitutional reform processes have been put in place to remedy the imbalance and lopsidedness in the Nigerian union to no great effect. The foundation was weak and has grown weaker over the years. The search for true federalism in post-colonial African states continues till date, with recent calls for the restructuring of the Nigerian nation. Lack of functional federalism has affected all sectors, including the education sector.

The breakdown of the elite classical model of University education in Nigeria continued at an escalated rate with the takeover of governments by military dictatorships in many parts of Africa. With military leadership in Nigeria came the absolute concentration of powers in the central government. The military constitutions in Nigeria, Ghana, Uganda, Libya amongst others accumulated several executive powers to the central government, thereby strangulating the capacity of the Regions and states to independently finance and execute education expansion programmes. Similarly, military governments exercised total control of all sectors, including education. The added impetus for military authorities to curtail student demands and protests, checkmate University Staff Unions led to the rise of governmental control and influence over key decisions in the education sector. Routine decisions such as constitution of University Governing Councils, university quotas, funding policies and structure became scrutinized by the Central Government. In the periods between 1966 and 1999, when Nigeria was under military rule, the Nigerian University system became increasingly less autonomous, less collegial, and highly dependent on government for funding and for decision making. Government

3 See Adebayo Oyebade (ed), The Foundations of Nigeria: Essays in Honor of Toyin Falola (Africa World Press 2003) 187; also Benedict I.C. Ijomah, Nigerian Nationalism and the Problems of Integration (Oluluben Publishers 2011) 20. 
involvement increased with controls over the constitution and membership of Governing Councils, direct control over the appointment of key administrative officers of Universities; and financial controls. Simply put, Government became a key stakeholder and decision maker in Nigeria's University systems.

These relics of military rule are unfortunately still present today. For example, it is beyond comprehension that almost 20 years after Nigeria returned to democratic governance in 1999, we have retained the 1999 Constitution, a constitution foisted on the country by the military regime, as our supreme law. This constitution, amongst other things, grants excessive control to the federal government to oversee and finance nearly all sectors of the economy.

Consequently, the reality of university education in Nigeria today remains that of perpetual demand by states for more financing from the federal government; and a consistent demand by university authorities for more autonomy to internally decide, run and execute their own programmes and policies.

\subsection{Where We Are Now}

My analysis so far goes back to the earlier question, which is: Shall we continue to blame the partition of Africa in 1884 in Berlin or the Mistake of Amalgamation of 1914 (104 years ago) for the rot in our educational systems? How sincere have we been in correcting some of the foundational and constitutional problems that continue to stifle our educational systems?

\subsection{Leadership Problem: True Federalism}

One of the most persistent and monumental failures of post-colonial Africa is leadership failure. Africa remains one of the most resourcerich continents on earth, in terms of mineral, natural and human resources. In addition to the serene greenery and magnificent wildlife in Kenya, South Africa and Calabar, Nigeria, Africa possesses 99 per cent of the world's chrome resources, 85 per cent of the world's platinum, 70 per cent of tantalite and 54 per cent of the world's gold, among others. Africa has six of the world's largest producers of oil and gas and holds huge deposits of diamond, bitumen and copper, among many others. Despite these geological affluence, is it not ironic and sad that Africa remains one of the poorest continents on earth in terms of per capita income and wealth? In all sectors, African leaders 
have failed to harness our abundant resources to properly consolidate on the positive achievements and structures put in place during Colonial Rule.

Africa is in urgent need of a new crop of leaders who are prepared to provide a vision for true federalism. We need leaders who will not sink back to primordial ethnic attachments nor be moored or covert bigotry. We need leaders who will invest their personal fortunes to develop their country. We need leaders who are prepared to make sacrifices as was done by Honourable Members of National Assembly, Regional Houses of Assembly, Local Government Council of 1960 to 1966 who were not paid salaries but sitting allowances which many like me did not collect. We need leaders who will make personal contributions to higher education which cannot be met by government alone as I did in University of Lagos. We need more Nigerians particularly the rich ones to invest in education by establishing not-for-profit firstclass institutions of learning similar to Afe Babalola University (ABUAD).

\subsection{Failure of Successive Governments to Invest Adequately in Education}

In the education sector, perennial failures by successive governments to prioritize investment in education has resulted in a situation whereby several of the infrastructure in place in several African universities are those erected pre-independence. Aside from the dilapidated classroom and laboratory infrastructure in several African universities due to age, many of the structures have been stretched beyond their original carrying capacity due to excessive demand traceable to overpopulation. As the United Nations Regional Bureau for Africa, recently noted:

The pace of skills and technology development and innovation has been slow in Africa, mainly because of the absence of a critical mass of highly university-educated skilled labour, and lack of high quality laboratories and scientific equipment...

\section{POOR WORKING CONDITIONS}

Lack of facilities, and deterioration of infrastructure as a result of age and rapid expansion, have stifled innovation, research and academic scholarship across Africa. Many of our best brains, such as Professor Wale Adebanwi, are here in Oxford, Harvard, etc., and have been unable to come back home due to poor working environment and lack of an 
innovative and supportive academic environment for world-class scholarship. As a World Bank study titled The Challenge of Establishing World-Class Universities, noted:

In academia, the adage "you get what you pay for" appears accurate regarding better-quality work being done where salaries are relatively highest. World-class universities are able to select the best students and attract the most qualified professors and researchers

The poor working conditions and environment in our universities have also reduced their global appeal and ability to recruit students from abroad. I recall that back in the days, University of Ibadan, Obafemi Awolowo University and the University of Lagos were like mini United Nations with students and lecturers from all over Africa and Europe. Apart from the diversity of thoughts that this global composition provided, it also created a platform for cultural, language and intellectual exchange on important issues of the day. Today, several African Universities have become local institutions, attended mainly only by local residents from the immediate state or region where the University is located. This has regressed to the current sad and sorry point whereby several faculty members now teach courses in local dialects.

This siloed and local approach was a fundamental flaw I was determined to correct when I established Afe Babalola University, Ado Ekiti. Not only did we carefully and selectively recruit brilliant lecturers from the United Kingdom, Romania and the United States, we also introduced a novel approach of globalizing our University by providing our students opportunities to learn multiple global languages. At ABUAD, students in all disciplines are provided the chance to learn Chinese and French. An ABUAD graduate is not just an engineer or a lawyer, but also a fully multilingual and globally ready professional. Based on a MOU that we have in place with China since 2011, every year, our students are provided the opportunity to travel to China on a three-week learning scholarship to sharpen their proficiency in Chinese language and culture. This is the sort of globalized learning approach that can spearhead our universities to become world-class.

Universities across Africa must adopt this global approach to learning. The complex trilemma that we, as university leaders, have is that: Our universities cannot be world-class until they begin to attract international students from all over the world. Our universities cannot 
attract students from all over the world until we have a globalized curriculum and course offering; we cannot have a globalized curriculum and course offering until we recruit dynamic and internationally trained experts and scholars who can lead such courses; and we cannot attract and recruit internationally trained experts and scholars until we have the courage and vision to innovate and dream big. Dreams come true if we work at it.

\subsection{Where We Need To Be}

The search for qualitative education in post-colonial Africa can only be successful if we invest time, efforts and resources in rebuilding our education infrastructure and capacities and, most importantly, reinvigorating the tenets of university autonomy, entrepreneurial education and citizenship education that were the hallmarks of colonial education structures. As Bof Taft, former Governor of Ohio in the US aptly puts it: "we must ensure our system of higher education offers world-class quality for a world-class economy."

First, there is a need to readopt a high investment approach on education. Building a world-class university for a world-class economy requires significant financial resources. Ranging from the cost of constructing and maintaining world-class learning infrastructure (including adequate buildings, well equipped lecture rooms, sanitation facilities, safe drinking water); recruiting highly qualified scholars both nationally and internationally; achieving a balanced lecturer-student ratio; and providing cutting-edge IT facilities, laboratories and research centres. All of these commitments require significant financial layout. This explains why developed countries spend a significant amount of their yearly budgets on education. Although the UNESCO High Level Group on Education for All has recommended that every country should spend no less than 15-20 per cent of yearly budgets on education, a spending threshold of 30 per cent of yearly national budget on education has been recommended as necessary for African countries to catch up and address the current infrastructure deficits.

Unfortunately, however, despite perennial rhetoric by successive African governments on their plans to build world-class universities, many have consistently failed to meet the UNESCO funding benchmark. For example, in the 2017 budget of Nigeria, N448.01 billion was allocated to education, representing only about 6 per cent of the N7.30 trillion of the federal budget. Failure to prioritize and devote significant resources to education has resulted in the perennial underfunding of 
our universities. Our universities simply do not have the financial wherewithal to compete with other universities around the world. With many of our universities struggling to meet their overhead cost, talk of having a significant net annual income is so far away. This points to an urgent need for the Nigerian government to inject financial stimulus into all Nigerian universities to make them financially equipped and self-sufficient.

Furthermore, developed countries have quickly realized that government alone, with all its responsibility for infrastructural development in other sectors, cannot construct and build the required quality universities that will accommodate the citizenry. That is why in addition to providing robust financial support for public universities, special financing is set aside to support the establishment of private universities that can bridge the gap of insufficient space for interested and qualified university candidates. Some of the greatest and most dynamic universities in the world are private universities. They include Harvard University, Yale University, and Stanford University as well as Afe Babalola University, among others. However, unlike Harvard, Yale and Stanford that have been extensively supported through direct research grants and aid by the American government, "the Nigerian government expects private universities to survive or perish at their own expense."

For instance, ABUAD is the first and only Nigerian University in history to have commenced operations with all Faculty buildings up and running on its permanent site. Similarly, ABUAD is the only institution in the country that currently has what is known as Talent Discovery Directorate where students are made to discover their gifted areas early enough and get mentored through provision of the right type of equipment until they are nurtured to stardom. Also, ABUAD recently commissioned its University Teaching Hospital, a state-of-theart and magnificent hospital, comparable to the best in the world. Only very recently, Aster Hospital, Dubai, the largest hospital in the Middle East entered into strategic partnership with ABUAD to provide high-level medical facilities and support in areas of providing maternal care, laparoscopy, emergency surgery, orthopaedics, liver care and more. It is the first university to own tele-medicine equipment.

Sadly, however, despite our efforts to spearhead technological research and innovation, Nigerian governments have done nothing to support those achievements and efforts. Instead, ABUAD, like all other private universities has been excluded from accessing University research 
funds such as TETfund which runs into billions of naira annually. TETfund is made up of 5 per cent levy on public and private companies to support education. Worse still, government also collects custom duties on education and hospital equipment freely donated by foreign philanthropists!!!

For Nigerian universities to compete with other universities across the world, there is a need for the Nigerian government to devote a significant portion of yearly budgets to revitalizing and supporting our universities, both private and public.

\subsection{Agriculture and Technology}

To achieve sustainable education in post-colonial Africa, there is an urgent need to return to the glory days whereby our universities focused on entrepreneurial and innovative learning in key sectors such as agriculture and technology. One of the most unfortunate symptoms of the collapse of our higher education sector is the progressive delivery of what I call "unsustainable education", i.e., mass education that contributes little or nothing to sustainable development and growth in Nigeria. Simply put, mass award of certificates with less socioeconomic development. Education that does not equip graduates to become independent thinkers, employers of labour, captains of industries and agents of economic change in key sectors of the economy is, in my view, unsustainable and irrelevant.

I ask you all today, of what use is a paper certificate when there is no food? Despite the vast amount of land resources in this country, youths roam the streets without jobs and without food. As university leaders, we must equip, train and empower our university graduates to take the lead in promoting agricultural revolution and ending the cycle of poverty in Nigeria. Sustainable education must result in significant economic and social change in Nigeria. The key is to promote Entrepreneurship and Innovation-driven Education in our Universities. As Elizabeth L. Hollander once remarked: "A generation that acquires knowledge without ever understanding how that knowledge can benefit the community is a wasted generation."

One of our most acknowledged strengths at ABUAD is our institutional commitment to what I call Innovative Agricultural Education. Innovative Agricultural Education refers to a systemic integration of Agriculture into Teaching, Research and Training. The three pillars of innovative agricultural education are agricultural research, practice-based learning and stakeholder engagement. 
With about 1000 hectares of farmland impeccably apportioned for farming, fishery, processing and packaging, the ABUAD Farm currently boasts 110,000 mango trees, over 500,000 teak trees, over 500,000 gmelina trees, 500,000 moringa trees, several hectares of cassava, maize, yam, soya-bean. We have 50 huge lakes each containing 50,000 fishes, 86 ponds each containing 5,000 fishes, feedmill, Moringa factory producing seven products (capsule, leaf powder, body butter, hair cream, tea, seed and oil), piggery, snailry, mushroom, guinea-fowl, turkey, quail, honey, among other things. To ensure their sustainability, a hatchery is on the farm to produce fingerlings while another complex on the farm houses the post-harvesting of the ponds.

The expansive ABUAD Farm encapsulates our vision and passion to provide total and holistic education to graduates and emerging Nigerian leaders by promoting Green Revolution. Our goal is to provide our students with "technical know-how" that will equip them to solve Nigeria's economic problems, and not add to it.

I extend an open invitation to and welcome each and every one of you here to please visit the ABUAD Farm to see why and how entrepreneurship must become the bedrock of our scholarly agenda in this country. By investing in Entrepreneurial Education, our universities can also diversify their income to become more self-sustaining. ABUAD Ventures, for example, contributes significantly to the internally generated revenue of our university. This way, the university can diversify its income and rely less on tuition and subvention payments from government.

The current governance approach of having underfinanced universities is a difficult path that cannot deliver sustainable and relevant education in Nigeria.

\section{HOW DO WE GET THERE?}

In this final part of my address, I will propose four key strategies that could assist in revitalizing our educational systems to become sustainable and world-class.

\subsection{National Restructuring and Constitutional Reform}

As I have noted, the brand of federalism practised across post-colonial Africa has stifled innovation and have made it difficult for states, private sector and even universities to attain the required level of financial and structural autonomy needed to drive sustainability. In Nigeria, for 
example, the uneven allocation of powers and responsibility between the federal and state governments is at the heart of the ongoing agitation for restructuring in the country. I recognize that federalism has no universally applicable template, as it is a context-specific notion that must be driven by the political and structural realities of every country. However, there are few common characteristics that are basic and fundamental to a true federation, the most important of which is: an equal distribution or allocation of powers, such that each unit has ultimate sovereignty, with none preeminent over or subordinate to the other. Both the federal and state tiers of government have their own separate democratic mandates and must retain substantial autonomy on a wide range of subjects to enable them run their governments and manage their affairs.

Given the size and diversity of a heterogeneous nation like Nigeria, it is inconceivable to expect that the federal government will be able to effectively finance and oversee the education sector. Currently, not only does the federal government have strong control over finances required to run the sector, the Exclusive Legislative list of the 1999 Constitution erroneously places the authority to regulate and "prescribe minimum standards for education at all levels" under the exclusive preserve of the federal government. Take Canada as an example, and you will find that the Canadian Constitution categorizes education as one of the matters "of a local nature" and vests the absolute control of education under the exclusive powers of the provinces and not the federal government. The same goes for the United States and Australia where each of the federating units has absolute autonomy and legislative responsibility to oversee their educational institutions.

This is the kind of reform and restructuring that we need in Nigeria and across Africa. Our current claims to being a federation is not only comical and deceitful; it indeed requires urgent surgical operation. Restructuring is not a call for disunity or conflict; it is a well-informed call for a speedy return to the confederation principles contained in the Independence Constitution which our Regional Leaders negotiated with the British between 1957 and 1959. It was on the basis of regional autonomy and true federalism that the Regions agreed to go to independence as one united country, and it remains the inevitable antidote for the multifaceted developmental challenges facing the Nigerian nation. 


\subsection{Education: Enforceable Right}

Another key reason why successive Nigerian governments have been able to get away with an uncommitted approach to university funding is the fact that the 1999 Constitution fails to provide a robust and enforceable recognition for the rights of every Nigerian to receive quality education. This has to be the starting point of our enquiry. The supreme law must recognize the basic right to education as a justiciable and enforceable right. The current constitution, fostered on Nigerians by the military in 1999, unscrupulously placed education under Chapter II called: the Fundamental Objectives and Directive Principles of State Policy. This portion of the Constitution indeed graciously and rightly provides that

The Government shall strive to eradicate illiteracy; and to this end Government shall, as and when practicable, provide (a) free, compulsory and universal primary education; (b) free secondary education; (c) free university education; and (d) free adult literacy programme.

While these are all very good and robust provisions, section 6, sub-section (6), paragraph (c) of the same Constitution however provides that the Judiciary shall have no powers to decide on any issue or question as to whether any act of omission by any authority or person is in conformity with the Fundamental Objectives and Directive Principles of State Policy. This provision makes it difficult, if not impossible, for citizens to sue the government for failing to provide affordable or quality education. In essence, like a Greek gift, the Constitution in one breadth contains wishful aspirations or dreams about education, and in another breath takes it away from the citizens. There is an urgent need to modify these archaic provisions and recognize education as an important and enforceable Fundamental Human Right. By so doing, students will have a robust legal basis to demand an enforcement of their rights to education in courts, rather than resorting to strikes and protests.

Without placing strong constitutional obligation on the Nigerian government to finance education at all levels, the current situation whereby the Nigerian government has failed to achieve the minimum 25 per cent of national budget or 4 per cent of GDP funding threshold specified by UNESCO may continue. 


\subsection{Need for a National Education Fund - State of Emergency on Education in Nigeria}

In my capacity as a former Chairman of the Committee of ProChancellors in Nigeria, I advocated, and I still advocate the need to declare a state of emergency in education both in Nigeria and much of Africa. To rapidly catch up with the rest of the world in terms of quality education, there is a need to establish National Emergency Funds for the education sector and designate a significant portion of annual budgets to education across Africa. For example, committing a minimum 25 per cent of national budget or 4 per cent of GDP each year to education would ensure that our education infrastructure deficit is slowly reduced, while demands for new infrastructure are met. Unfortunately, the Nigerian government is yet to embrace the need for priority funding for higher education, same as several other African countries.

This regrettable lack of political will is also noticeable in the fact that Nigeria has a Sovereign Wealth Fund currently worth about US $\$ 1.50$ billion, being savings from excess crude oil sales. The Nigerian Sovereign Investment Authority has identified four key priority sectors that will benefit from the 5-year priority Infrastructure Investment programme of the fund and they are: agriculture, healthcare, real estate, power and motor ways. Despite the huge infrastructure deficit in our education sector, it beats my imagination that education is not recognized as a priority sector that deserves strategic and focused high priority investment. This is a situation that we must all address. Investment in education must be a priority of any responsible nation.

Similarly, African Universities must engage with International Development Partners to explore international funding opportunities. Several organizations, such as the UK's Department for International Development (DFID), World Bank, USAID, African Development Bank, Qatar Foundation, Bill and Melinda Gates Foundation, among others, are actively seeking to partner with our universities in areas of financing projects and research efforts.

As some of you know, very recently ABUAD received a US\$40 million expansion loan from the African Development Bank. This pathbreaking funding is designed to fast-track ABUAD's world-class infrastructural development strategy. It was specifically provided to make ABUAD a Centre of Excellence for tertiary education in Africa by expanding access to high-quality education to over 10,000 students per year. The expansion plan consists of construction of new facilities - 
including a 400-bed teaching hospital, an industrial research park, and a small hydro power (SHP) installation (1.1 MW). Beyond doubling ABUAD's current student capacity, the project will create 250 new staff positions, as well as about 1,000 temporary jobs across the construction, supplies and consulting in the value chain. Full/partial scholarships and other forms of substantial financial aid will be provided to over 500 student beneficiaries during the life of the financing. Our universities can go very far by attracting such international partnership and financing.

It is the task of the century for all African universities to enhance their capacities, readiness and attractiveness for international partnerships. International Funding Agencies are interested in Africa, but the question is, are we ready and attractive to them? Opportunity, they say, favours only the prepared.

\subsection{Curriculum Expansion for Innovation and Agricultural Education}

An essential foundation for achieving sustainable education in Africa is promoting a holistic mainstreaming of innovation and agriculture into teaching curriculum, in order to encourage students to take control of their own future.

The importance of innovation cannot be overemphasized. It is not a mere coincidence that Africa's glorious years in terms of national economic development were years when our universities were equally known for delivering significant innovation and research. Zimbabwe was known as the bread basket of the continent due to expansive agriculture; Nigeria was known as the largest exporter of cocoa and cassava. South Africa was known for high innovation.

However, what do we have today? Due to poor funding, brain drain, infrastructural deficiency, poor ethical standards and different levels of institutional corruption, our universities can no longer drive innovation. Many of our African economies are primarily agriculture-based. Yet we continue to perpetuate the colonial approach to education which was designed for that time to train skilled secretaries and white collar officers that were needed for the work force. Times have changed, the demands of our time have changed, yet we have failed to change. In the UK, as well as other developed countries, universities are the key to spearheading research, applied technology, and economic growth. Take Canada, for example, where Aeronautical Engineering Departments have spurred key breakthroughs for aviation infrastructure, making Canada a leading manufacturer of aeroplanes (the Bombardier). Electrical 
Engineering and Computer Science departments have also provided talented graduates who drive Canada's electronics and software industry, which generates US $\$ 50$ billion in annual exports. Furthermore, several Oxford professors have won Nobel Prizes in Medicine, Engineering and Sciences. Unless we drive and finance innovation in our universities, Africa will continue to depend on foreign technology and goods as the foundation for its infrastructural projects. This is an approach that has failed us for several years and will continue to do so. Countries that have achieved meaningful development realized this and have dedicated significant national funding to research and innovation.

As a University Administrator, I know the depth of human and intellectual capacity locked behind the gates of our Universities. If wellfunded and motivated, our universities hold the key to unlocking sustainable infrastructural development and agricultural innovation in Nigeria. The rapid development and growth of Afe Babalola University shows me that private universities have prominent roles to play in national development and should be funded and encouraged to do so. Government must create an enabling environment for our universities to drive innovation in Nigeria if we seriously wish to achieve educational security and sustainable development.

\subsection{Address Population Explosion - A Peculiar African Factor}

In rounding off, I want to address a serious factor that has affected education sector in post-colonial African states. This factor is peculiar to Africa, and unless we deal with it effectively and decisively, our search for sustainable education would end in vain. This peculiar factor is the "Population Factor".

It is common knowledge that the population of African countries south of the Sahara is increasing rapidly. The geometric rise in population certainly impacts negatively on the yearly revenue of the government and the amount the government can reasonably budget for education. I believe that African countries should relate the growth in population of their country to the resources available to government in the midst of several needs they had to provide for. Taking Nigeria as an example, the population of Nigeria which was only 40 million in 1961 is now 198 million.

It is unfortunate that while other countries are curtailing population growth, Africans revel in producing children without caution. When China woke up to the reality of population explosion starring it in the 
face, it pegged the number of children in a family to one. On the contrary, we continue to revel in the unwholesome habit of giving birth to a multitude of children. For example, one recalls the story of a 93-yearold Bello Abubakar in Nigeria who had 97 wives and 185 children. As a matter of fact, Bello had, at some point, had 107 wives but the number got reduced to 97 after he had divorced 10 of them.

The government is called upon to make it abundantly clear that there is a limit in the amount of money it can provide for education in the midst of competing areas of needs. The African leaders should stop deceiving the populace that if elected, they will provide free education. This is how we in Nigeria came about establishing several state universities which are only universities in name and are not better than glorified secondary schools.

\section{CONCLUSION}

A combination of legal, political and cultural factors has rendered the search for sustainable education in post-colonial Africa illusory and utopian. They include lack of true federalism among the states created at the Berlin Conference in 1884 having regard to amalgamation of many incompatible tribes; failure of successive African government to invest adequately in education; failure of the government to sensitize the public that no government alone can fund quality and functional education; lack of support for private institutions for research and educational development by government; inadequate emphasis on innovation and entrepreneurship in our educational institutions; poor leadership; uncontrolled population; poor working conditions and environment in our university; and failure to adopt a global approach to learning.

All hope is however not lost. We all, as Africans, and major stakeholders and leaders in the higher education sector, have pivotal, sacred and indispensable roles to play in contributing our strategic opinions and efforts to reversing the current trend. As John Galbraith, an economist and public intellectual, once noted:

All of the great leaders have had one characteristic in common: it was the willingness to confront unequivocally the major problems of their people in their time. This, and not much else, is the essence of leadership.

Our University, Afe Babalola University is doing that. Looking around this room today, I am confident that we have the requisite human and 
intellectual resources to unequivocally tackle and address the pressing challenges facing our universities. I very much look forward to working with you to make it happen.

Finally, I reiterate my profound sense of gratitude to this University, particularly the Director of the African Studies Centre and Rhodes Professor of Race Relations, Prof. Wale Adebanwi, for the invitation extended to me to discuss this topical and interesting subject. That Oxford University has established international reputation as a Centre of Academic Excellence is not in dispute. It is my wish that the firmament of academic light burning from this university will continue to glow and attract the attention of would-be scholars from around the world.

Ladies and Gentlemen, I thank you once again for the opportunity given to me and for your time. 